\title{
Behavioral Economics in Consumer Behavior Analysis
}

\author{
Gordon R. Foxall ${ }^{1}$
}

Published online: 12 October 2017

(C) Association for Behavior Analysis International 2017

Since its inception, consumer behavior analysis has sought to meld behavioral psychology, behavioral economics, and marketing science into a unified whole that comprehends consumer behavior in a unique way (Foxall, 1990/2004, 2011; Hantula, DiClemente, \& Rajala, 2001). A special issue of the journal Managerial and Decision Economics was recently devoted to operant behavioral economics, and I am delighted that this special issue of The Behavior Analyst brings together further contributions of that discipline to consumer behavior analysis. With it, I would like to renew my invitation to consumer behavior analysis (Foxall, 2010): This is an inclusive field of endeavor, and all are welcome to the interdisciplinary party.

The term behavioral economics has recently become popular in a number of contexts, but it refers to rather different approaches that display little by way of shared methodology or even a common view of the nature of human behavior and the factors of which it is a function. The behavioral economics of Herbert Simon (e.g., 1979) suggests, for instance, that firms and consumers do not maximize but "satisfice," producing satisfactory results rather than acting optimally, simply because humans do not have the information or the cognitive skills that would be required to maximize. Moreover, Kahneman and Tversky (e.g., 1984) have demonstrated dramatically that people's behavior often deviates substantially from the norms of economic theory. And a range of behavior change strategies such as "nudging," which entails making small changes in behavior - modifying it incrementally rather than seeking to make major alterations all at once - have seized the popular imagination (Sunstein \& Thaler, 2009).

All of these approaches actually try to go beyond economics as a discipline. To the extent they have anything in common, it is their critical view of orthodox economics and a desire to replace at least some of it with a combined psychology and economics framework of conceptualization and analysis. Above all, however, they seek to promote an approach to behavior that is more descriptive of what people actually do than is usually the case for economics in general. The behavioral economics that has its roots in the

Gordon R. Foxall

foxall@ cardiff.ac.uk

1 Cardiff Business School, Cardiff University, R03, Aberconway Building, Colum Road, Cathays, Cardiff, Wales CF10 3EU, UK 
confluence of behavior analysis and microeconomics (Hursh, 1980, 1984), to which we might now refer as operant behavioral economics, is less critical of economics than any of these, but, like them, it includes psychology and is closely in touch with the actual behavior of consumers and producers (Foxall, 2016a). Consumer behavior analysis draws upon this confluence of the behavioral psychology and microeconomics that comprise operant behavioral economics, relating them to the behavior of consumers as it is revealed by consumer research and marketing science (Foxall, 1998; Hantula et al., 2001; Hantula \& Wells, 2013). Recent contributions include a volume dedicated to a wide range of theoretical and empirical studies (Foxall, 2016b) and a succinct introduction to consumer behavior analysis as a means of integrating behavior analysis, behavioral economics, and marketing science (Foxall, 2017). The purpose of this special issue is to mark the continuing conceptual and empirical progress of consumer behavior analysis.

In their article, "Contributions of Behavior Analysis to Behavioral Economics," Elise Frølich Furrebøe and Ingunn Sandaker elucidate the unique contributions made by behavior analysis to behavioral economics, particularly its opening the way for the adoption of a selectionist perspective, its elaboration of the principle of reinforcement as a means of exploring the functional relationships between consumption and its outcomes, and the single-subject research paradigm that it makes available. In these ways, a behavior-analytically based behavioral economics provides the scope for consumer behavior analysis to apply not only to consumer choice in the context of modern marketing-oriented economics, which has overwhelmingly provided its purview thus far, but also to alternate kinds of economies and even to nonhuman animal behavior. The following articles illustrate the methodological and substantive range of investigation that is open to behavior analysts of consumption.

Peter G. Roma, Derek D. Reed, Florence D. DiGennaro Reed, and Steven R. Hursh continue the theme of operant behavioral economics in their article, "Progress of and Prospects for Hypothetical Purchase Task Questionnaires in Consumer Behavior Analysis and Public Policy," which provides a status report on the use of a hypothetical purchase task questionnaire as a means of gathering data on consumers' behavior as a prelude to policy formulation. This method represents a useful innovation for consumer research within the behavior-analytic or behavioral economic framework.

Another technique for data collection in consumer research is in-store observation and the opportunity for field experimentation it provides. Nils Magne Larsen, Valdimar Sigurdsson, and Jørgen Breivik ("The Use of Observational Technology to Study InStore Behavior: Consumer Choice, Video Surveillance, and Retail Analytics") describe the retail environment as a laboratory for applied behavior-analytic research, an extension of the operant chamber to naturally occurring behavior settings. These authors discuss the contribution that operant behavioral economics provides for the study of the initial phase of grocery shopping: the selection of the means of carrying chosen products in the form of a cart, a basket, or one's arms. Their research framework incorporates a molecular fourterm contingency, coupled with a molar methodology that incorporates conversion-rate modeling, where actual choice behavior is detected through video surveillance.

Online consumer behavior occupies a large proportion of research endeavor in consumer research generally and in consumer behavior analysis. Valdimar Sigurdsson, R. G. Vishnu Menon, and Asle Fagerstrøm are among the pioneers of the latter, and their article, "Online Healthy Food Experiments: Capturing Complexity by Using Choice-Based Conjoint Analysis," describes the principles of empirical investigation that uses conjoint 
analysis. This technique is particularly suitable for the study of complex consumer behavior, that which is not amenable to direct experimental analysis, and may also form an initial stage of a research project that also incorporates experimental methods.

As a means of making the three- (or $n$-) term contingency relevant to the analysis of consumer behavior in natural settings, the behavioral perspective model (BPM; Foxall, $1990 / 2004$, 2010) proposes that consumption is reinforced by both utilitarian (functional) rewards and informational (social) rewards. The immediate precursor or context of consumer choice is the consumer behavior setting, which comprises the consumer's learning history, and the discriminative stimuli and motivating operations that relate to the pattern of utilitarian and informational reinforcement likely to follow a consumer behavior, such as brand or product purchase or use. The last four articles in this special issue are concerned in differing ways with the evaluation of this model and its contributions to understanding consumer choice. They also illustrate the spectrum of quantitative techniques relevant to research in this area.

Max Greene, Peter Morgan, and Gordon Foxall explore the capacity of connectionist models to shed light on the nature of consumer choice. Their article, "Neural Networks and Consumer Behavior: Neural Models, Logistic Regression, and the Behavioral Perspective Model," indicates the superiority of neural network modeling to logistic regression in the prediction of consumer loyalty and confirms the contribution of measures of utilitarian and informational reinforcement to the explanation of consumer choice.

Andrew Rogers, Gordon Foxall, and Peter Morgan use and evaluate a Bayesian model to explicate consumer behavior. In "Building Consumer Understanding by Utilizing a Bayesian Hierarchical Structure Within the Behavioral Perspective Model," they use the BPM structure in order to formulate a more complex Bayesian model as the basis for hypothesis testing. In the course of this, they introduce a hierarchical structure into the BPM that is compared to a nonhierarchical structure of the same model. The merits of the Bayesian approach to calculating parameter inference are then identified and discussed.

In "Consumer Maximization of Utilitarian and Informational Reinforcement: Comparing Two Utility Measures With Reference to Social Class," Jorge Oliveira-Castro and Gordon Foxall extend research that uses Cobb-Douglas utility functions to indicate that consumers maximize utility as a function of the level of utilitarian and informational reinforcement provided by the brands they purchase (see Oliveira-Castro, Cavalcanti, \& Foxall, 2016a, 2016b). In the version of the previously tested model that is the subject of their article, they incorporate measures of consumer utility at the level of the aggregate household, as well as per consumed product unit, and investigate how obtained utility is related to consumers' social class and age.

The concluding article, "Temporal Discounting and Marketing Variables: Effects of Product Prices and Brand Informational Reinforcement," by Jorge Oliveira-Castro and Rafaela Marques returns to a familiar theme among behavioral economists: delay discounting. Their aims were to ascertain whether temporal discounting is better described by an exponential or a hyperbolic function; whether differently priced products differ with respect to temporal discounting rates; and whether brands offering different levels of informational reinforcement differ with respect to temporal discounting rates.

Research in consumer behavior analysis is affecting both behavioral economics and marketing science, and its effects are being felt in a number of fields both within and 
beyond behavior analysis (e.g., Foxall, 2015; Hantula, Brockman, \& Smith, 2008). The contents of the Managerial and Decision Economics special issue, which are listed in the appendix Table 1, bear strong testimony to this. I hope that the articles in this issue convey some of the potential of operant behavioral economics in the analysis of consumption and marketing and the excitement of researchers in this area. I am grateful to the Editor-in-Chief, Dr. Donald A. Hantula, for his invitation to edit this special issue and for his assistance, especially in regard to the articles of which I am a coauthor. I also wish to thank Ms. Lonalyn Blando, who represents the publisher and who has provided me with invaluable assistance from a practical, editorial point of view. Finally, I am most grateful to the authors who contributed to this issue and to the reviewers who responded so positively to yet another call on their valuable time and intellectual effort.

\section{Appendix}

Table 1 Contents of the Special Issue of Managerial and Decision Economics on Operant Behavioral Economics, Volume 37, Issues 4-5, May 2016

\begin{tabular}{|c|c|c|}
\hline Author(s) & Title & Page range \\
\hline Foxall & "Operant Behavioral Economics" & $215-223$ \\
\hline Hursh \& Roma & $\begin{array}{l}\text { "Behavioral Economics and the Analysis of Consumption and } \\
\text { Choice" }\end{array}$ & $224-238$ \\
\hline Baum & "Driven by Consequences: The Multiscale Molar View of Choice" & $239-248$ \\
\hline Rachlin & "Social Cooperation and Self-Control" & $249-260$ \\
\hline Ainslie & $\begin{array}{l}\text { "The Cardinal Anomalies That Led to Behavioral Economics: } \\
\text { Cognitive or Motivational?" }\end{array}$ & $261-273$ \\
\hline $\begin{array}{l}\text { Jamolowicz, Reed, } \\
\text { DiGennaro Reed, \& } \\
\text { Bickel }\end{array}$ & $\begin{array}{l}\text { "The Behavioral and Neuroeconomics of Reinforcer Pathologies: } \\
\text { Implications for Managerial and Health Decision-Making" }\end{array}$ & $274-293$ \\
\hline Hantula \& Crowell & $\begin{array}{l}\text { "Matching and Behavioral Contrast in a Two-Option Repeated } \\
\text { Investment Simulation" }\end{array}$ & $294-305$ \\
\hline Roma \& Hursh & $\begin{array}{l}\text { "Hypothetical Purchase Task Questionnaires for Behavioral } \\
\text { Economic Assessments of Value and Motivation" }\end{array}$ & $306-323$ \\
\hline $\begin{array}{l}\text { Fagerstrøm, Aksnes, \& } \\
\text { Arntzen }\end{array}$ & $\begin{array}{l}\text { "An Experimental Study of Intertemporal Choices: The Case of } \\
\text { Customer Relationship Management" }\end{array}$ & $324-330$ \\
\hline $\begin{array}{l}\text { Fagerstrøm, Ghinea, \& } \\
\text { Sydnes }\end{array}$ & $\begin{array}{l}\text { "How Does Probability Impact Consumers' Choice? The Case } \\
\text { of Online Reviews" }\end{array}$ & $331-336$ \\
\hline $\begin{array}{l}\text { Sigurdsson, Hinriksson, \& } \\
\text { Vishnu Menon }\end{array}$ & $\begin{array}{l}\text { "Operant Behavioral Economics for E-Mail Marketing: } \\
\text { An Experiment Based on the Behavioral Perspective Model } \\
\text { Testing the Effectiveness of Motivational Operation, } \\
\text { Utilitarian and Informational Stimuli" }\end{array}$ & $337-344$ \\
\hline Vishnu Menon \& Sigurdsson & $\begin{array}{l}\text { "Conjoint Analysis for Social Media Marketing Experimentation: } \\
\text { Choice, Utility Estimates and Preference Ranking" }\end{array}$ & $345-359$ \\
\hline $\begin{array}{l}\text { Oliveira-Castro, Cavalcanti, } \\
\text { \& Foxall }\end{array}$ & $\begin{array}{l}\text { "What Consumers Maximize: Brand Choice as a Function of } \\
\text { Utilitarian and Informational Reinforcement" }\end{array}$ & $360-371$ \\
\hline
\end{tabular}




\section{References}

Ainslie, G. (2016). The cardinal anomalies that led to behavioral economics: cognitive or motivational? Managerial and Decision Economics, 37, 261-273.

Baum, W. (2016). Driven by consequences: the multiscale molar view of choice. Managerial and Decision Economics, 37, 239-248.

Fagerstrøm, A., Aksnes, D., \& Arntzen, E. (2016a). An experimental study of intertemporal choices: the case of customer relationship management. Managerial and Decision Economics, 37, 324-330.

Fagerstrøm, A., Ghinea, G., \& Sydnes, L. (2016b). How does probability impact consumers' choice? The case of online reviews. Managerial and Decision Economics, 37, 331-336.

Foxall, G. R. (1998). Radical behaviorist interpretation: generating and evaluating an account of consumer behavior. The Behavior Analyst, 21, 321-354.

Foxall, G. R. (2004). Consumer psychology in behavioral perspective. Frederick, MD: Beard Books (Original work published 1990).

Foxall, G. R. (2010). Invitation to consumer behavior analysis. Journal of Organizational Behavior Management, 30, 92-109.

Foxall, G. R. (2011). Interpreting consumer choice: the behavioral perspective model. New York, NY: Routledge.

Foxall, G. R. (2015). Consumer behavior analysis and the marketing firm: bilateral contingency in the context of environmental concern. Journal of Organizational Behavior Management, 35, 44-69.

Foxall, G. R. (2016a). Operant behavioral economics. Managerial and Decision Economics, 37, 215-223.

Foxall, G. R. (Ed.). (2016b). The Routledge companion to consumer behavior analysis. New York, NY: Routledge.

Foxall, G. R. (2017). Advanced introduction to consumer behavior analysis. Cheltenham: Elgar.

Hantula, D. A., Brockman, D., \& Smith, C. L. (2008). Online shopping as foraging: the effects of increasing delays on purchasing and patch residence. IEEE Transactions on Professional Communication, 51, 147-154.

Hantula, D. A., \& Crowell, C. R. (2016). Matching and behavioral contrast in a two-option repeated investment simulation. Managerial and Decision Economics, 37, 294-305.

Hantula, D. A., DiClemente, D. F., \& Rajala, A. K. (2001). Outside the box: the analysis of consumer behavior. In L. Hayes, J. Ausgen, \& R. Fleming (Eds.), Organizational change (pp. 203-233). Reno, NV: Context Press.

Hantula, D. A., \& Wells, V. K. (Eds.). (2013). Consumer behavior analysis: (a) rational approach to consumer choice. London: Routledge.

Hursh, S. R. (1980). Economic concepts for the analysis of behavior. Journal of the Experimental Analysis of Behavior, 34, 219-238.

Hursh, S. R. (1984). Behavioral economics. Journal of the Experimental Analysis of Behavior, 42, 435-452.

Hursh, S. R., \& Roma, P. (2016). Behavioral economics and the analysis of consumption and choice. Managerial and Decision Economics, 37, 224-238.

Jamolowicz, D., Reed, D., DiGennaro Reed, F. D., \& Bickel, W. K. (2016). The behavioral and neuroeconomics of reinforcer pathologies: implications for managerial and health decision-making. Managerial and Decision Economics, 37, 274-293.

Kahneman, D., \& Tversky, A. (1984). Choices, values, and frames. American Psychologist, 39, 341-350.

Oliveira-Castro, J. M., Cavalcanti, P., \& Foxall, G. R. (2016a). What consumers maximize: brand choice as a function of utilitarian and informational reinforcement. Managerial and Decision Economics, 37, 360-371.

Oliveira-Castro, J. M., Cavalcanti, P., \& Foxall, G. R. (2016b). What do consumers maximize? The analysis of utility functions in light of the behavioral perspective model. In G. R. Foxall (Ed.), The Routledge companion to consumer behavior analysis (pp. 202-212). London: Routledge.

Rachlin, H. (2016). Social cooperation and self-control. Managerial and Decision Economics, 37, $249-260$.

Roma, P., \& Hursh, S. R. (2016). Hypothetical purchase task questionnaires for behavioral economic assessments of value and motivation. Managerial and Decision Economics, 37, 306-323.

Sigurdsson, V., Hinriksson, H., \& Vishnu Menon, R. G. (2016). Operant behavioral economics for e-mail marketing: an experiment based on the behavioral perspective model testing the effectiveness of motivational operation, utilitarian and informational stimuli. Managerial and Decision Economics, 37, 337-344.

Simon, H. A. (1979). Rational decision making in business organizations. The American Economic Review, 69, 493-513.

Sunstein, C. R., \& Thaler, R. H. (2009). Nudge: improving decisions about health, wealth, and happiness. London: Penguin.

Vishnu Menon, R. G., \& Sigurdsson, V. (2016). Conjoint analysis for social media marketing experimentation: choice, utility estimates and preference ranking. Managerial and Decision Economics, 37, 345-359. 